\title{
Wage share and economic growth in Latin America, 1950-2011
}

\author{
Germán Alarco Tosoni
}

ABSTRACT

This article builds series of wage shares in gross domestic product (GDP) for 15 Latin American economies individually and as a group for the period 1950-2010. Using different methodologies, it is established that wage share is non-linear and has undergone two major cycles. The article discusses various authors, especially classic and post-Keynesian thinkers, who have explored the relationship between wage share in GDP and economic activity. It is also shown that the post-Keynesian approach is relevant in explaining that the main variables determining real GDP variations include wage share, gross capital formation and exports of goods and services. However, the contribution of wage share to real output growth has declined from the 1980s onwards. 


\section{I}

\section{Introduction}

The link between the factor distribution of income and activity levels and economic growth is an old one reaching back to classical economists and examined in detail by the post-Keynesian school. In recent times, in most Latin American economies, efforts have focused on the analysis of personal income distribution at the household level. In standard macroeconomics, position in the production process (wage earners, own-account workers, owners of the means of production and financiers) is not considered in the diagnosis or in specific recommendations. Moreover, the statistics available on this position have deteriorated. The first challenge of redeeming theories that treat functional income distribution as relevant is thus the need to rebuild the data.

This statistical work is preceded by that of Lindenboim (2008), who uses information on wage share in output for a group of developed countries from the 1950s onwards, and for some in the region starting in 1980. The conclusion is clear for the developed economies, where the wage share rose up to the 1960s, then stood still or fell amid the crisis of "Fordism", except in Denmark. In the case of Latin America, there is simply a downtrend with the occasional fluctuation in individual economies. Only Chile and Colombia show sustained growth in certain periods.

Along the same lines, Neira Barría (2010) rebuilt the information on wage participation in GDP at factor cost for 14 countries and the weighted aggregate for Latin America, with output at purchasing power parity in constant dollars at 1970 prices for 1950-2000 and wage shares based on census information, including the wages of own-account or self-employed workers. ${ }^{1}$ In the aggregate, and using unprocessed basic information, Neira Barría found an upward phase until the mid-1970s, thereafter falling to a trough around 1983. The wage

$\square$ Acknowledgements are owed to Favio Leiva Cárdenas and Brian Cevallos Fujiy as project assistants. The author would like to express thanks to Patricia del Hierro Carrillo for her comments and to anonymous reviewers of an earlier version of this article for their observations. Any remaining errors or omissions are the sole responsibility of the author. Thanks are also expressed to Juan M. Graña for providing the basic series on wage participation in output in Argentina.

1 These workers are traditionally included in the operating surplus. For independent workers Neira Barría assumes the same average pay as for wage workers, not including unpaid family workers and other unpaid workers. share in output then entered a recovery, which peaked around the mid-1990s. This was followed by another downward period. Neira Barría found sharp variations between and within countries, however.

The International Labour Organization (ILO, 2012) has also engaged in this statistical and analytical effort, although with information from selected countries starting in the 1980s. A comparative analysis of productivity and wage share in different subregions in Latin America between 2000 and 2010 is available in ECLAC/ILO (2012). Other works encompass longer periods, dating back to the nineteenth century for certain countries (Argentina, Brazil and Mexico (Frankema, 2009), with a trough found around the time of the First World War), and for the countries of the Southern Cone, where inequality was found to rise between 1870 and 1920 (Bértola and others, 2008).

This article uses reconstructed statistical information to review the evolution of wage share in GDP in Latin America, comparing this variable to the evolution of real GDP to assess the extent to which real GDP is explained by wage share and other components of aggregate demand under a post-Keynesian approach. The main questions are: How has wage share evolved? How does that share relate to changes in real GDP? What theoretical approaches relate wage share to level of activity and economy growth? How does the post-Keynesian approach evaluate the link between these variables? Is this approach useful for analysing the evolution of growth in Latin America?

This article has seven sections, including the introduction, conclusions and methodological annex. The second section provides basic information on wage share in the different Latin American economies, finding that it is uneven in terms of starting and ending dates. The third section reviews some of the main theoretical contributions regarding the variables analysed. This review touches, first, on some classical economists, with the macroeconomic approaches of Keynes, Kalecki and some post-Keynesians. The fourth section presents the basic model in the post-Keynesian rationale, which treats wage share as relevant in explaining real output level. The fifth section conducts an empirical analysis of causal links between wage share, GDP and output growth share. The sixth section sets forth the conclusions of the study and the seventh contains the methodological annex. 
The scope and limitations of this study are such that it does not offer a detailed analysis of every economy considered. The analysis is conducted at the macroeconomic level and does not touch upon structural and sociopolitical specificities of each economy. It does not examine the issues of urban and rural independent workers whose situation could be similar in practice to

\section{II}

\section{Basic statistics}

The main variable of analysis is the wage share in GDP at current prices, which is obtained from the quotient between nominal information from each country for each year, and the corresponding output. Statistical information is included for 15 countries in the region between 1950 and 2011, although the period is not evenly covered in all cases, since information is lacking for the 1950s. The analysis includes Argentina (1950-2011), Bolivarian Republic of Venezuela (1957-2011), Brazil (1950-2011), Chile (1950-2010), Colombia (1950-2010), Costa Rica (19532011), Ecuador (1953-2011), El Salvador (1960-2011), Honduras (1950-2011), Mexico (1950-2011), Panama (1950-2011), Paraguay (1962-2010), Peru (1950-2011), Uruguay (1955-2010) and Plurinational State of Bolivia (1960-2011). It does not include Guatemala, Nicaragua or the Dominican Republic, because the information for these countries is too fragmented.

The first source of information is the Statistical Yearbook for Latin America and the Caribbean for various years, published by the Economic Commission for Latin America and the Caribbean (ECLAC), as well as electronic statistics (ECLAC, 2013) from 1988 on. Where this information was insufficient, International Labour Organization (ILO) data were used, considering that presented by national sources in each case (first the official data, failing which, third party data prepared on the basis of the official data). Only in extreme case in which primary or secondary local information was not available, was the procedure retrieved by which wage share $(w)$ was generated for specific years on the basis of average real wages $\left(W_{t}\right)$, the waged population $\left(L_{t}\right)^{2}$ and real GDP $\left(Y_{t}\right)$. In all cases, particular care was taken

\footnotetext{
${ }^{2}$ Exceptionally, employed population was used when there was no information on the waged population.
}

that of wage workers. It does not enter into issues of value theory, or its link with prices and income distribution. Neither does it undertake theoretical discussion or statistical evaluation of the Kuznets curve, which looks at the link between personal income inequality and economic growth. Lastly, it does not look specifically at whether the demand regime is wage-led or profit-led.

with the linking of the various statistical series, always using the most recent source. Accordingly, equation (1) gives the calculation of wage share in GDP.

$$
w_{t}=\frac{\left(W_{t} L_{t}\right)}{Y_{t}}
$$

Applying differences between year $t$ and $t-1$ and dividing by $w_{t-1}$, the growth rate of wage share in $\mathrm{GDP}^{3}$ is shown in equation (2), where $\gamma_{x t}$ is the growth rate of variable $x$ in year $t$. This expression thus gives an idea of what happened in years for which no information in available, based on the value for the preceding year. Particulars of the information by country are shown in the annex to this article.

$$
\frac{\Delta w_{t}}{w_{t-1}}=\frac{\left(1+\gamma_{w_{t}}\right)\left(1+\gamma_{L_{t}}\right)}{1+\gamma_{Y_{t}}}-1
$$

Table 1 shows some variables for the series of wage share in GDP for different countries in Latin America and for the region for the period 1950-2010. ${ }^{4}$ First, the number of observations, the mean, the standard deviation and the coefficient of variation..$^{5}$ Next, the maximum and minimum values are shown, along with

\footnotetext{
${ }^{3}$ On the premise that average wages are representative of the respective country's wage structure and that the GDP deflator is similar to the price index used to convert nominal wages into real wages.

${ }^{4}$ This is the case of Argentina, Brazil, Chile, Colombia, Honduras, México, Panama and Peru, which represent between $80 \%$ of regional output for the 15 countries selected in 1960 and $92 \%$ in 1994 .

5 As is known, the coefficient of variation is the ratio of the standard deviation to the mean, during the period examined. It is acknowledged that the coefficient of variation can vary from one economy to another and over time, but a detailed analysis of this is beyond the scope of this study.
} 
their dates of occurrence. Finally, table 1 shows the moving trend indicator ${ }^{6}$ and the number of complete cycles after a Hodrick-Prescott filter is applied to calculate non-linear trends.

The highest averages for wage share are found in Panama, Costa Rica, Honduras, Brazil, Argentina, Uruguay and Chile; the lowest occur in Ecuador, El Salvador and Peru. The Bolivarian Republic of Venezuela, Colombia, Mexico, Paraguay and the Plurinational State of Bolivia, are in intermediate positions. However, Panama, Ecuador, El Salvador, Peru, Argentina, Uruguay and the Bolivarian Republic of Venezuela show a higher standard deviation than Costa Rica and Brazil, which show the lowest standard deviations. The most stable coefficients of variation were found in Costa Rica, Brazil and Paraguay, and the most unstable in Ecuador, Panama, El Salvador and Peru. The dates at which the various countries achieve the highest wage share in GDP vary.

${ }^{6}$ The results of the moving trend indicator $\varnothing=\frac{\sum_{n-9}^{n} X_{i}}{\sum_{1}^{10} X_{i}}$ give the ratio between the last result of the moving average (10) and the first. A ratio of around 1 indicates a constant trend; a ratio of more than 1 indicates a rising trend; and a ratio of less than 1 indicates a falling trend.
The minimum values tend to occur after the debt crisis of the 1980s. In Honduras and El Salvador, they occur at the end of the 1950s and early 1960s. The maximum values arise both at times of intensive importsubstitution industrialization -Bolivarian Republic of Venezuela, 1960; Brazil, 1957; Peru, 1958; and Uruguay, 1963 - and at certain sociopolitical junctures that were favourable to workers: Argentina, 1974; Chile, 1972; Colombia, 1993; Costa Rica, 1990; Ecuador, 2007; El Salvador, 1981; Honduras, 1986; Mexico, 1976; Panama, 1969; Paraguay, 2000; and the Plurinational State of Bolivia, 1984.

On the basis of the techniques described, economies were identified whose long-term trend is more or less consistent over time, those that showed an upward trend and those that showed a downward trend over the long term. Of the entire group, only Honduras showed an upward trend over time; Ecuador and El Salvador report a high value for the indicator, but it is extremely cyclical. The countries in which the trend is more or less constant over time are Brazil, Chile, Colombia, Costa Rica and, to a lesser extent, Mexico and Paraguay. The last group consists of those countries showing a downward trend, with the most negative evolution in Panama and Peru, followed by Argentina, Bolivarian Republic of Venezuela, and Plurinational State of Bolivia. Notwithstanding, in

TABLE 1

Main characteristics of wage share in GDP in Latin America

\begin{tabular}{lccccccccccc}
\hline Country & Coverage & $\begin{array}{c}\text { No. of } \\
\text { observations }\end{array}$ & $\bar{X}$ & $\bar{\sigma}$ & $\overline{\bar{\sigma}}$ & $\begin{array}{c}\text { Maximum } \\
\text { value }\end{array}$ & $\begin{array}{c}\text { Date of } \\
\text { maximum } \\
\text { value }\end{array}$ & $\begin{array}{c}\text { Minimum } \\
\text { value }\end{array}$ & $\begin{array}{c}\text { Date of } \\
\text { minimum } \\
\text { value }\end{array}$ & $\begin{array}{c}\text { Average moving } \\
\text { indicator }(\mathrm{t}=10)\end{array}$ \\
Cycles
\end{tabular}

Source: prepared by the author on the basis of data from the World Bank, the Economic Commission for Latin America and the Caribbean (ECLAC), the International Labour Organization (ILO) and institutions of the respective countries.

GDP: gross domestic product. 
many of the economies there were one or two complete cycles during the period under analysis. Two cycles were observed in Argentina, the Bolivarian Republic of Venezuela, Brazil, Chile, Mexico, Panama and Uruguay, while the other countries showed only one cycle or a pattern that is less clear-cut.

Figure 1 shows wage share in GDP for the 15 economies analysed on the basis of the original information corrected by the Hodrick-Prescott filter, which serves to determine the non-linear trend of statistical series. The figure shows the results by country groupings: larger economies, medium-sized economies, smaller economies, and the Central American economies. A first, obvious observation is that levels and fluctuations vary between countries, reflecting the complexity of the structural factors associated with the economic, social, political and accumulative models that shape shares in GDP, although the maximum and minimum values noted earlier were observed in the group overall. In Argentina the cycles are more pronounced than in Brazil, which is different again from the cycle in Mexico. The second group of economies is notable for the downtrend from the 1970s peak in Peru, the cyclical pattern in Chile, and the cases of Colombia and Bolivarian Republic of Venezuela, with peaks in the 1980s and the 1960s, respectively. Of the smaller Latin American economies, variability is notably low in the Plurinational State of Bolivia, but sharper in Ecuador according to the official information. Lastly, among the Central American economies, the trend is least cyclical in Costa Rica,

FIGURE 1

Wage share in GDP corrected by Hodrick-Prescott filter, 1950-2010

(Percentages of GDP)

Larger economies

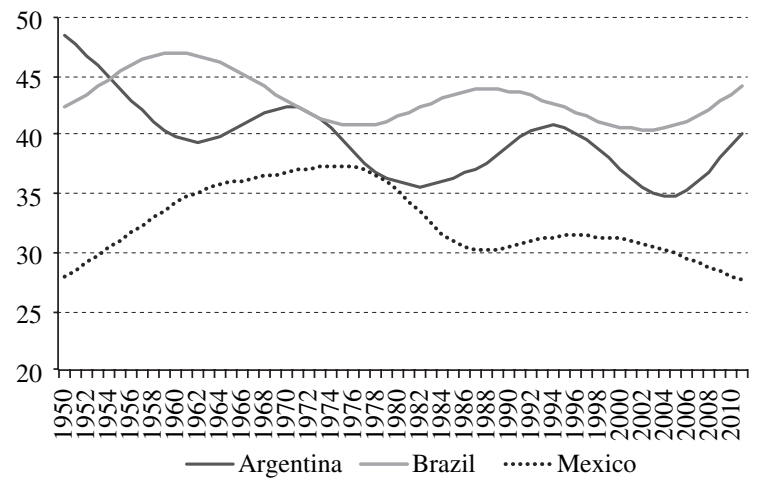

Smaller economies

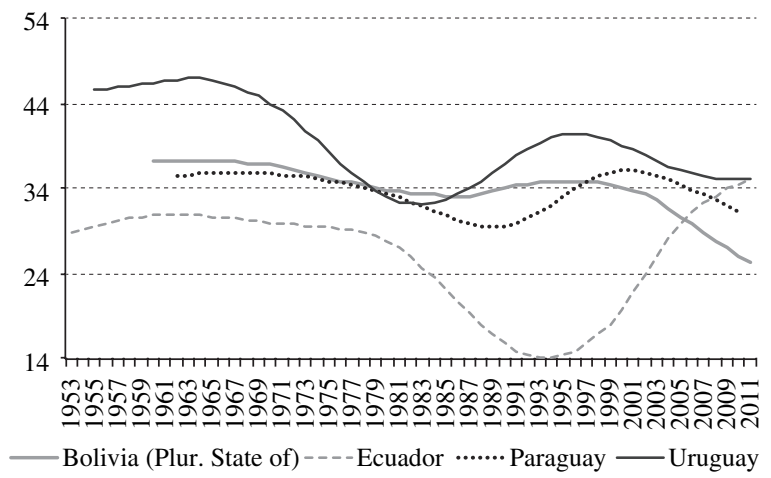

Medium-sized economies

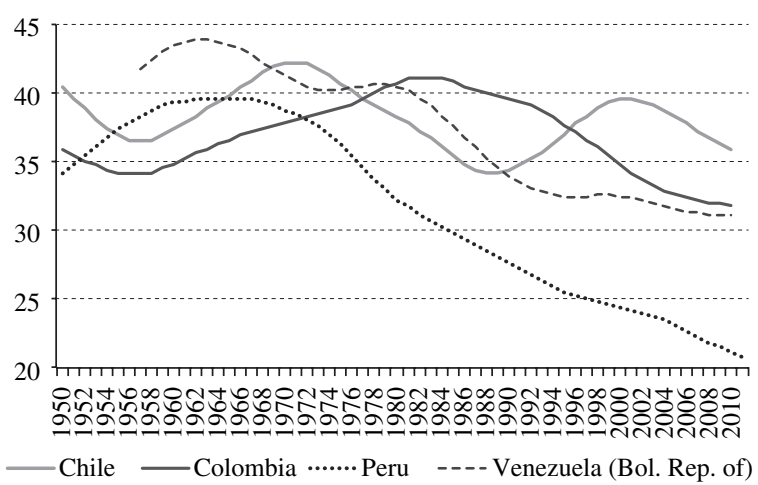

Central American economies

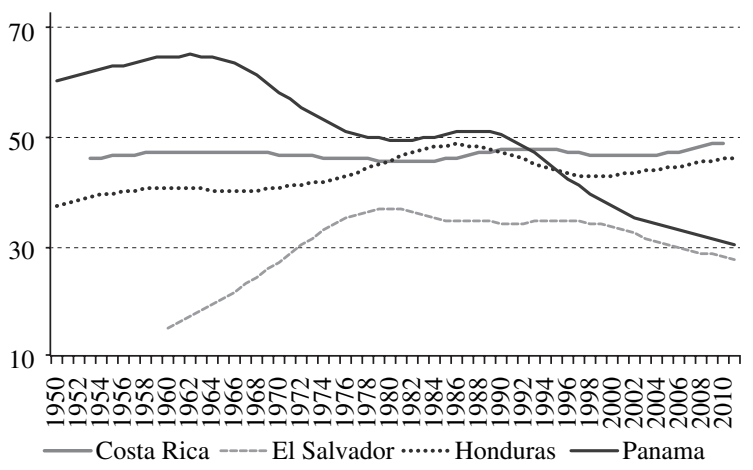

Source: prepared by the authors, on the basis of data from the World Bank, the Economic Commission for Latin America and the Caribbean (ECLAC), the International Labour Organization (ILO) and institutions of the respective countries.

GDP: gross domestic product. 
followed by Honduras. The information is more variable for Panama and El Salvador, and is for a shorter period of time.

The series for Latin America for 1950-2010, weighted by nominal GDP in current dollars, ${ }^{7}$ shows wage participation averaging $38.8 \%$, with a small standard deviation only slightly higher than that of Costa Rica. The coefficient of variability is small, with a peak of $41.7 \%$ in 1967 , a time when several of the region's economies were engaged in import-substitution industrialization. The low in the coefficient of variability was $33.7 \%$ in 2004 , down eight percentage points from the 1967 peak. Two full cycles were identified for the 61-year series, along with a negative trend shown by a moving trend indicator of less than 1 .

Figure 2 shows the original series for wage share in GDP and the various results as a non-linear trend calculated using the Hodrick-Prescott filter, the Epanechnikov kernel

${ }^{7}$ With the World Bank series starting in 1960 and the ECLAC series for $1950-1960$. indicator ${ }^{8}$ and the 10-year moving average. The largest wage shares were found to have occurred in the late 1960s and early 1970s and the mid-1990s, with higher values for the first cycle than the second. By contrast, the periods with smaller wage shares correspond to the debt crisis of the 1980s and the middle of the first five-year period of the twenty-first century, owing to the impact of the Argentine crisis. Wage share in GDP then begins to rise in the second five-year period of this century, owing to the larger contribution made by Argentina and Brazil. The rest of the countries make a minimal contribution to this rise (Colombia and Honduras) or even a negative one (Chile, Mexico, Panama and Peru). Over the long term, Argentina and Brazil are the economies pushing up the wage share in Latin America. Chile is at the average, whereas Colombia, Mexico, Panama and Peru tend to pull the average down.

\footnotetext{
${ }^{8}$ In this case, an 11-point moving average whose weighting factors come from a probability distribution which is symmetric with respect to the number of points. The series of coefficients is as follows: $\{0.04$; $0.07 ; 0.09 ; 0.11 ; 0.12 ; 0.13 ; 0.12 ; 0.11 ; 0.09 ; 0.07$, and 0.04 .
}

FIGURE 2

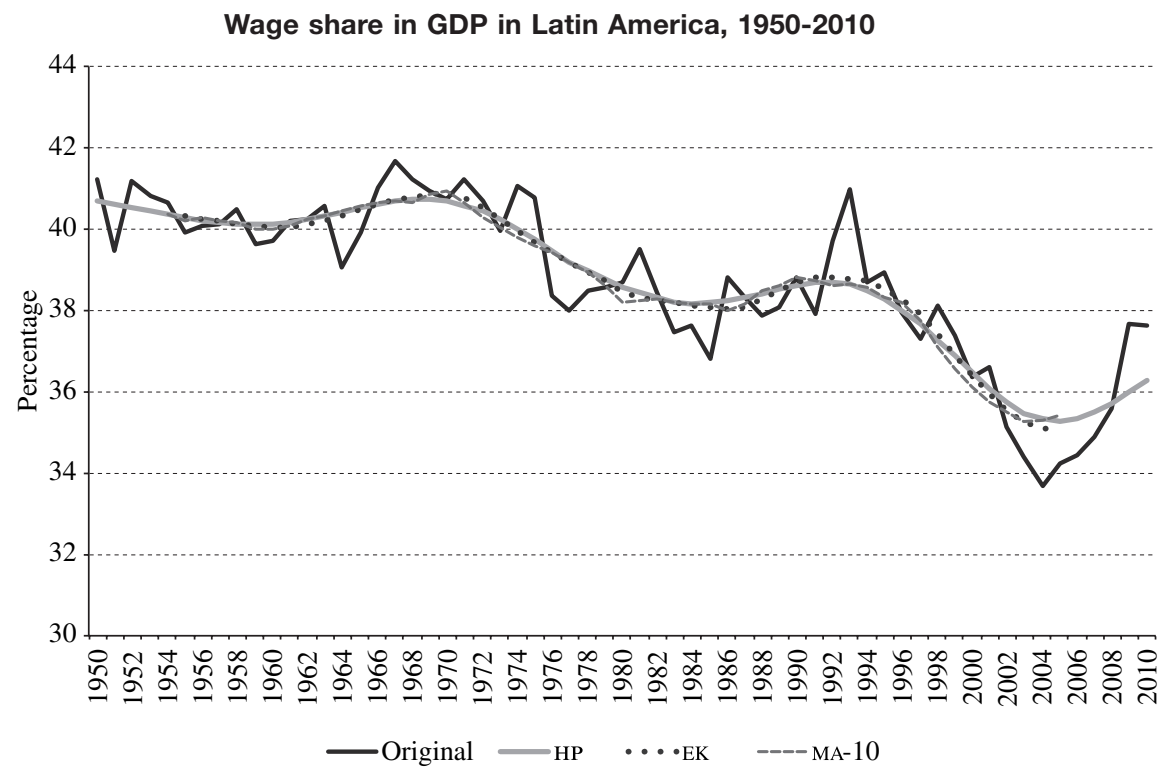

Source: prepared by the author on the basis of data from the World Bank, the Economic Commission for Latin America and the Caribbean (ECLAC), the International Labour Organization (ILO) and institutions of the respective countries.

GDP: gross domestic product.

HP: Hodrick-Prescott.

EK: Epanechnikov kernel

MA-10: 10-year moving average. 


\section{III}

\section{Theoretical contributions over time}

Smith (1776), a champion of better living conditions for the lowest earners - the majority in every societyargued that: "No society can surely be flourishing and happy, of which the far greater part of the members are poor and miserable. It is but equity, besides, that they who feed, clothe and lodge the whole body of the people, should have such a share of the produce of their own labour as to be themselves tolerably well fed, clothed and lodged". In the same chapter on the wages of labour, he noted that a moderate abundance (high wages) over the usual will likely lead workers to work harder, as they will feel more encouraged. Smith also notes that when rising wages impact on the prices of products and thus slow their domestic and external consumption, they are generally accompanied by rising capital endowments, which increases manufacturing productivity and spreads to society and the economy overall. Thus, many of these goods are produced with less labour than before, so that the rise in prices is offset by the fall in the number of workers needed (Smith, 1776).

Unlike Smith, Ricardo (1959) considers economic growth to be essentially the work of capitalists - the productive class in society - who consume a small part of what they obtain and devote their returns to capital accumulation. The idea, then, is to prevent profits from decreasing to zero, because at that point the capitalist can accumulate no more, growth stops and the system grinds to a halt (Pasinetti, 1978). The profit rate cannot rise unless wages are reduced through technical progress and foreign trade (i.e. through imports), that lower the prices of essential goods (Ricardo, 1959, p. 101). Both Malthus and Ricardo opposed the Poor Laws, on the basis that wages should be left to free market competition and never controlled or influenced through legislation. They argued that the Poor Laws did not enrich the poor, but impoverished the rich, since the funds needed for the maintenance of the poor would grow to absorb the country's entire net revenue (Ricardo, 1959, pp. 80-81).

Marshall (1957) did not resolve the paradox that had swept aside the entire issue analysed by the neoclassical school up to the 1930s crisis. He acknowledged that raising the living standards of the population at large would increase both efficiency and national well-being (p. 566), but also that it could render the population more unfortunate than before (p. 567). Starting with Marshall, all association between wage share and level of economic activity was lost, as a result, first, of emphasis on microeconomic analysis and, later, of the division between consumer theory and producer theory. Say's Law and, later, Walras's Law would minimize the effects of this evident delinking.

The link between wage share and economic growth surfaces again with Keynes (1943), although only implicitly though the marginal propensity to consume and the multiplier, ${ }^{9}$ becoming more explicit in Keynes' economic policy recommendations. Wages are the main component of income and determine propensity to consume, which - in turn - determines the spending multiplier. Consumption propensity is not constant for all levels of employment, however, or for all degrees of foreign trade openness, or for different labour shares in public investment. It also depends on the financial behaviour of firms. Moreover, it varies with changes in the proportion of total income accruing to businessowners, who tend to show a lower individual consumption propensity than the average for the community (p. 113). In chapter 24, Keynes signals more clearly that "it is, of course, true that a fiscal policy of heavy death duties ${ }^{10}$ has the effect of increasing the community's propensity to consume" (Keynes, 1943, p. 329), which contributes to capital accumulation. Abstinence by the rich, however, slows the accumulation of wealth.

Kalecki (1954) refers explicitly to the income distribution relationship, in particular the wage burden vis-à-vis income, on the basis of supply side pricing processes and their involvement in determining demand and production levels. In the first case, the wage share in income depends on the degree of monopoly of the particular industry, the ratio between wages and spending on raw materials in that industry and the industry structure (p. 31). The share of wages in income or in output thus depends inversely on elements such as product differentiation (sales promotion through advertising), processes of concentration and involvement in tacit agreements or cartels; and directly on the strength of the unions and how variations in overheads with respect to primary costs influence the degree of monopoly.

\footnotetext{
9 This is shown by Kaldor (1955).

${ }^{10}$ Income taxes and death duties tend to redistribute the income from rich to poor ones, raising the average propensity to consume in society and increasing the spending multiplier.
} 
Kalecki determines the level of demand and economic activity on the basis of the explanatory factors of profits, derived from the principle of effective demand by social class: capitalists earn what they spend, whereas wage earners spend what they earn. Gross earnings are thus determined by levels of consumption (which depend on the level of earnings), investment, the export surplus (exports minus imports) and the budget deficit. ${ }^{11}$ Assuming that the wage burden depends on output level, output depends on the earnings determined by a multiplier which takes into account the share of the wage burden in output. In sum, when private investment increases, the export surplus and the budget deficit push up output, depending on the multipliers linked to capitalists' propensity to consume and the wage share in output. Output increases faster if these multipliers rise, but more slowly if they fall.

Kaldor (1955), taking a post-Keynesian approach, analyses the links between earnings, investment and level of economic activity, noting that the wage share in output depends on the level of investment in relation to output and the various propensities to save of wage earners and capitalists. ${ }^{12}$ In the extreme case in which wage earners save nothing at all, earnings depend solely on the level of investment adjusted inversely for capitalists' propensity to save, which will be equivalent to the traditional spending multiplier. In this respect, Kaldor holds that his finding is similar to that of Kalecki, and becomes more sensitive when workers save part of their wages. Later, Pasinetti (1979) makes a small

\footnotetext{
${ }^{11}$ Insofar as the private sector of the economy receives more in the form of government spending than it pays in tax. Strictly speaking, gross savings by capitalists and workers should be deducted from gross profits.

12 Which should be understood as $1-C_{i}$, where $C_{i}$ are the different propensities to consume of wage earners and capitalists.
}

\section{IV}

\section{Basic model}

Kalecki (1954) models the level of economic activity on the basis of the balance between supply and aggregate demand. This model is reprised by authors such as Ocampo (1988), who notes that, on the income side, income can be broken down into profits after $\operatorname{tax}\left(G_{a}\right)$, wages $(S)$, imports and taxes $(I)$. On the demand side, the variables are equivalent to consumption by owners $(C P)$, correction, to the effect that an individual who saves part of their income then owns it. Workers who have saved will thus receive a portion of the total profits. What is interesting about this correction is that it gives similar results to those of Kaldor, but without assuming that wage earners' propensity to save is equal to zero. Workers' propensity to save, then, does not influence the distribution of income between profits and wages, nor does it influence the rate of profit (Pasinetti, 1979, p. 94).

Ros (2004) gives an account of the economic and sociopolitical mechanisms through which inequality affects economic growth. The economic mechanisms include the negative impacts of inequality on the market size of industries with increasing returns to scale or on aggregate demand, with severe impacts on investment, and other indirect effects which link inequality to slower population growth and birth rates. The sociopolitical impacts include degree of political stability and social conflict triggered by inequality and the polarization that undermines agreement on economic policy — which in turn makes it difficult to manage external shocks if there is no consensus on the distribution of the adjustment burden.

More recently, post-Keynesian models have proposed different growth regimes. At one extreme is the wage-led regime, under which a rise in the wage share pushes up aggregate demand and GDP via the impact on investment levels of higher private consumption. However, this regime could lead to a reduction in export competitiveness and lower investment. At the other extreme, under a demand-led regime an increase in the wage share would lead to lower aggregate demand, if investment were highly susceptible to a reduction in profit margins. In this rationale, high profitability can encourage firms to expand their capacity and increase investment. Lower wage levels would also contribute to export growth (Stockhammer, 2011).

consumption by wage earners $(C A)$, gross fixed capital formation $(F)$, exports $(E)$ and public spending $(G)$. To bring the model closer to reality it is assumed that imports can be consumption goods $(I C)$, intermediate goods $(I I)$ and capital goods $(I B K)$ as shown in equation (3). In equations (4), (5) and (6), owners consume a proportion $\left(\theta_{0}\right)$ of their profits, capital goods 
imports are a proportion of total investment $\left(\theta_{1}\right)$ and saving by wage earners $(A s)$ is the difference between their wages and consumption. Removing profits from (3) and incorporating the other formulas gives (7).

$$
\begin{gathered}
Y=G a+S+I I+I C+I B K+I=C A+C P+F+E+G \\
C P=\theta_{0} G a \\
I B K=\theta_{1} F \\
S-C A=A s \ldots \\
G a\left(1-\theta_{0}\right)=F\left(1-\theta_{1}\right)+(G-I)+(E-I I-I C)-A s
\end{gathered}
$$

Equation (8) establishes that wages maintain a proportion of private sector gross income (wY) which is also equivalent to the gross income of the private sector minus profits. ${ }^{13}$ Next, equation (9) establishes that imports of intermediate goods are a proportion of gross national output $\left(\theta_{2}\right)$. Equation (10) is obtained from equations (8) and (9) in (7). Output would then be determined by the exogenous components of demand

\footnotetext{
13 For simplicity's sake, a constant was not included as a parameter in the equations for consumption by owners, in imports of intermediate goods or in fluctuations of wage share in output.
}

included in the numerator: net exports, gross capital formation in national goods and the difference between public spending and taxes. The denominator includes wage share in GDP, owners' propensity to consume and the propensity to import intermediate goods which are part of the spending multiplier.

Equation (11) estimates the contribution of wage share to output. A higher wage share in output will give a higher output, unless the value of the exogenous demand components included in the numerator is negative. This is unlikely, however, because the national component of gross capital formation should be neutralized by the fiscal surplus, the presence of negative net exports and a high rate of savings by wage earners.

$$
\begin{gathered}
S=Y-G a=w Y \\
I I=\theta_{2} Y \ldots \\
Y=\frac{F\left(1-\theta_{1}\right)+(G-I)+(E-I C-A s)}{\left[(1-w)\left(1-\theta_{0}\right)+\theta_{2}\right]} \\
\frac{\partial Y}{\partial w}=\frac{\left(1-\theta_{0}\right)\left[F\left(1-\theta_{1}\right)+(G-I)+(E-I C-A s)\right]}{\left[(1-w)\left(1-\theta_{0}\right)+\theta_{2}\right]^{2}}
\end{gathered}
$$

\section{V}

\section{Empirical evaluation}

As a first assessment, a Granger causality test is performed for wage share and the evolution of real GDP for the different Latin American economies and the regional average calculated on the basis of information from eight countries. The information on real GDP is expressed in constant dollars at 2000 prices. This information is taken from the World Bank and complemented by ECLAC. ${ }^{14}$ The Granger causality test is a statistical test to assess causal primacy between two groups of variables, i.e. whether wage share determines GDP, or GDP determines

\footnotetext{
14 The World Bank now presents information from 1960, whereas the ECLAC data cover the earlier period and are also useful for recent years in the case of Argentina. In all cases, the splicing was performed using a simple rule of three.
}

wage share. The model in section IV shows that causality runs from wage share to output more than the reverse (GDP causes wage share in Granger terms) when wage share is small or the economy's strongest drivers are government sources (consumption and public investment), private investment or the external sector (exports and openness to imports). However, it should be recalled that the Granger test analyses information-based - not intuitive or factual- causality.

Table 2 shows the results of the Granger test on wage share in GDP and the evolution of real GDP by country and for the region for the entire period of analysis. The exercise was performed using information obtained by applying a Hodrick-Prescott filter to determine the nonlinear trends for both series. This criterion was used rather 
than the observed data, because of the latter's variability in response to short-term and other structural factors not explored in this work. In any case, in the second section of the article it is shown that the result obtained from applying the Hodrick-Prescott filter is similar to that obtained from applying the moving averages and the Epanechnikov kernel indicator.

In 8 of the 15 Latin American economies examined, the relationship envisaged in the theory was borne out: in all the tests performed, causality runs from wage share to GDP more than the reverse. In another five cases, the dominant relation is the reverse, but it cannot be ruled out that wage share determines GDP. Only in one case can causal primacy of GDP over wage share be established. With a 95\% confidence level, the hypothesis that GDP causes wage share was rejected for Argentina, the Bolivarian Republic of Venezuela, Chile (with the highest level of rejection), Costa Rica, Ecuador, El Salvador, Peru and the Plurinational State of Bolivia. GDP causing wage share is not rejected in Brazil, Colombia, Honduras, México, Panama and Paraguay. The wage share causality of GDP is rejected only in the case of Uruguay. For Latin America overall, in which Brazil and Mexico weigh heavily, GDP causality of wage share is not rejected at $95 \%$ confidence, but neither is wage share causality of GDP rejected at $90 \%$ confidence.

TABLE 2

\section{Granger causality tests between wage share and real GDP for economies in Latin America \\ (Hodrick-Prescott filter: 3 lags)}

\begin{tabular}{|c|c|c|c|}
\hline Null hypothesis & $\begin{array}{c}\text { No. of } \\
\text { observations }\end{array}$ & F-statistic & Log-odds \\
\hline Real GDP in Argentina does not cause wage share & 59 & 1.41 & 0.25 \\
\hline Wage share in Argentina does not cause real GDP & 59 & 4.98 & 0.00 \\
\hline Real GDP in Bolivia (Plurinational State of) does not cause wage share & 49 & 3.49 & 0.02 \\
\hline Wage share in Bolivia (Plurinational State of) does not cause real GDP & 49 & 11.73 & 0.00 \\
\hline Real GDP in Brazil does not cause wage share & 59 & 3.19 & 0.03 \\
\hline Wage share in Brazil does not cause real GDP & 59 & 1.37 & 0.26 \\
\hline Real GDP in Chile does not cause wage share & 58 & 1.37 & 0.26 \\
\hline Wage share in Chile does not cause real GDP & 58 & 13.11 & 0.00 \\
\hline Real GDP in Colombia does not cause wage share & 58 & 8.57 & 0.00 \\
\hline Wage share in Colombia does not cause real GDP & 58 & 6.35 & 0.00 \\
\hline Real GDP in Costa Rica does not cause wage share & 55 & 2.85 & 0.05 \\
\hline Wage share in Costa Rica does not cause real GDP & 55 & 8.85 & 0.00 \\
\hline Real GDP in Ecuador does not cause wage share & 56 & 5.91 & 0.00 \\
\hline Wage share in Ecuador does not cause real GDP & 56 & 8.77 & 0.00 \\
\hline Real GDP in El Salvador does not cause wage share & 49 & 6.46 & 0.00 \\
\hline Wage share in El Salvador does not cause real GDP & 49 & 11.47 & 0.00 \\
\hline Real GDP in Honduras does not cause wage share & 59 & 11.34 & 0.00 \\
\hline Wage share in Honduras does not cause real GDP & 59 & 9.06 & 0.00 \\
\hline Real GDP in Mexico does not cause wage share & 59 & 11.61 & 0.00 \\
\hline Wage share in Mexico does not cause real GDP & 59 & 7.79 & 0.00 \\
\hline Real GDP in Panama does not cause wage share & 59 & 9.35 & 0.00 \\
\hline Wage share in Panama does not cause real GDP & 59 & 5.54 & 0.00 \\
\hline Real GDP in Paraguay does not cause wage share & 46 & 42.27 & 0.00 \\
\hline Wage share in Paraguay does not cause real GDP & 46 & 24.62 & 0.00 \\
\hline Real GDP in Peru does not cause wage share & 59 & 3.73 & 0.02 \\
\hline Wage share in Peru does not cause real GDP & 59 & 6.27 & 0.00 \\
\hline Real GDP in Uruguay does not cause wage share & 54 & 4.30 & 0.01 \\
\hline Wage share in Uruguay does not cause real GDP & 54 & 0.30 & 0.82 \\
\hline Real GDP in Venezuela (Bolivarian Republic of) does not cause wage share & 51 & 6.98 & 0.00 \\
\hline Wage share in Venezuela (Bolivarian Republic of) does not cause real GDP & 51 & 9.25 & 0.00 \\
\hline Real GDP in Latin America does not cause wage share & 58 & 3.69 & 0.02 \\
\hline Wage share in Latin America does not cause real GDP & 58 & 2.13 & 0.11 \\
\hline
\end{tabular}

Source: prepared by the author, on the basis of data from the World Bank, the Economic Commission for Latin America and the Caribbean (ECLAC), the International Labour Organization (ILO) and institutions of the respective countries.

GDP: gross domestic product. 
Table 3 shows the results of the Granger causality tests for Latin America overall, with the period 19502011 divided into two subperiods, 1950-1985 and 19862011 , on the premise that a structural shift occurred in the region after the debt crisis of the 1980s, whereby the inward-looking production pattern -in which a higher wage share was central to the model - gave way to an outward-looking pattern in which wage share was less important. Like table 2, table 3 assesses the dominant causality between the information obtained on wage share from the application of the HodrickPrescott filter, and real GDP. It also looks at the wage share causality of percentage variation in real GDP, and at wage share percentage variation causality of percentage variation in real GDP. For the subperiods 1950-1985 and 1986-2011, the null hypothesis that wage participation does not cause real GDP is rejected for both percentage variations. Regarding the relationship between wage share and real GDP, and that between wage share and percentage variation both for 1950-2011 and for 1986-2011, it cannot be rejected in the first instance that real GDP causes wage share; neither can it be rejected that wage share causes real GDP.

TABLE 3

Granger causality tests between wage share and real GDP for Latin America: 19501985 (3 lags) and 1986-2011 (2 lags)

\begin{tabular}{|c|c|c|c|}
\hline Null hypothesis & $\begin{array}{c}\text { No. of } \\
\text { observations }\end{array}$ & F-statistic & Log-odds \\
\hline $\begin{array}{l}\text { Real GDP of Latin America 1950-1985 does not cause wage share } \\
\text { Wage share of Latin America does not cause real GDP }\end{array}$ & 33 & $\begin{array}{r}11.23 \\
3.70\end{array}$ & $\begin{array}{l}0.00 \\
0.02\end{array}$ \\
\hline $\begin{array}{l}\Delta \ln \text { (real GDP of Latin America) } 1950-1985 \text { does not cause wage share } \\
\text { Wage share of Latin America does not cause } \Delta \ln \text { (real GDP of Latin America) }\end{array}$ & 32 & $\begin{array}{r}10.35 \\
5.36\end{array}$ & $\begin{array}{l}0.00 \\
0.01\end{array}$ \\
\hline $\begin{array}{l}\Delta \ln (\text { real GDP of Latin America) } 1950-1985 \text { does not cause } \Delta \ln \text { (wage share) } \\
\Delta \ln \text { (wage share of Latin America) does not cause } \Delta \ln (\text { real GDP) }\end{array}$ & 32 & $\begin{array}{l}4.74 \\
7.30\end{array}$ & $\begin{array}{l}0.01 \\
0.00\end{array}$ \\
\hline $\begin{array}{l}\text { Real GDP of Latin America 1986-2011 does not cause wage share } \\
\text { Wage share of Latin America does not cause real GDP }\end{array}$ & 23 & $\begin{array}{r}170.98 \\
16.71\end{array}$ & $\begin{array}{l}0.00 \\
0.00\end{array}$ \\
\hline $\begin{array}{l}\Delta \ln \text { (real GDP of Latin America) } 1986-2011 \text { does not cause wage share } \\
\text { Wage share of Latin America does not cause } \Delta \ln \text { (real GDP of Latin America) }\end{array}$ & 22 & $\begin{array}{l}17.65 \\
60.87\end{array}$ & $\begin{array}{l}0.00 \\
0.00\end{array}$ \\
\hline $\begin{array}{l}\Delta \ln (\text { real GDP of Latin America) } 1986-2011 \text { does not cause } \Delta \ln \text { (wage share) } \\
\Delta \ln (\text { wage share of Latin America) does not cause } \Delta \ln (\text { real GDP) }\end{array}$ & 22 & $\begin{array}{l}1.22 \\
9.53\end{array}$ & $\begin{array}{l}0.32 \\
0.00\end{array}$ \\
\hline
\end{tabular}

Source: prepared by the author, on the basis of data from the World Bank, the Economic Commission for Latin America and the Caribbean (ECLAC), the International Labour Organization (ILO) and institutions of the respective countries.

GDP: gross domestic product.

$\Delta \ln$ : natural log differences.

Figure 3 shows the relationship between the nonlinear trend of wage share and output (left scale) and percentage variations in the trend of real GDP (right scale), both calculated after applying a HodrickPrescott filter. Three clear stages may be observed in the relationship between the two variables. In the first, lasting until the early 1980s, the two variables are very closely associated. After the 1980s and into the 1990 s, the relation still appears to be direct, but weaker. Lastly, since the early twenty-first century wage participation and real GDP percentage variation have been moving in opposite directions. Figure 4 shows how the percentage variation in wage share has evolved in relation to the percentage variation in real GDP for the same period of analysis. As in figure 3 , there is a direct relation between the variables in the 1950s, 1960s and 1970s, but they move in opposite directions in the 1980s and 1990s. Since the year 2000 there has been a direct relation between the percentage variations, but a weak one.

Table 4 shows selected regressions of the percentage variation of real GDP in Latin America in relation to wage share, which is part of the spending multiplier and the other exogenous components of demand, under the postKeynesian model presented in their third section. The table shows four of the selected regressions, where the percentage variation of real GDP is a lagged function of wage share in the same period, the sum of gross capital formation, exports of goods and services and a dummy variable for Latin America as a region. Unfortunately, there is no information on public finances, propensity to consume and other variables included in the theoretical model for the period under analysis. The contribution of imports to the percentage variation of real GDP 
FIGURE 3

Wage share and real GDP growth in Latin America, 1950-2010

(On the basis of data with Hodrick-Prescott filtering)

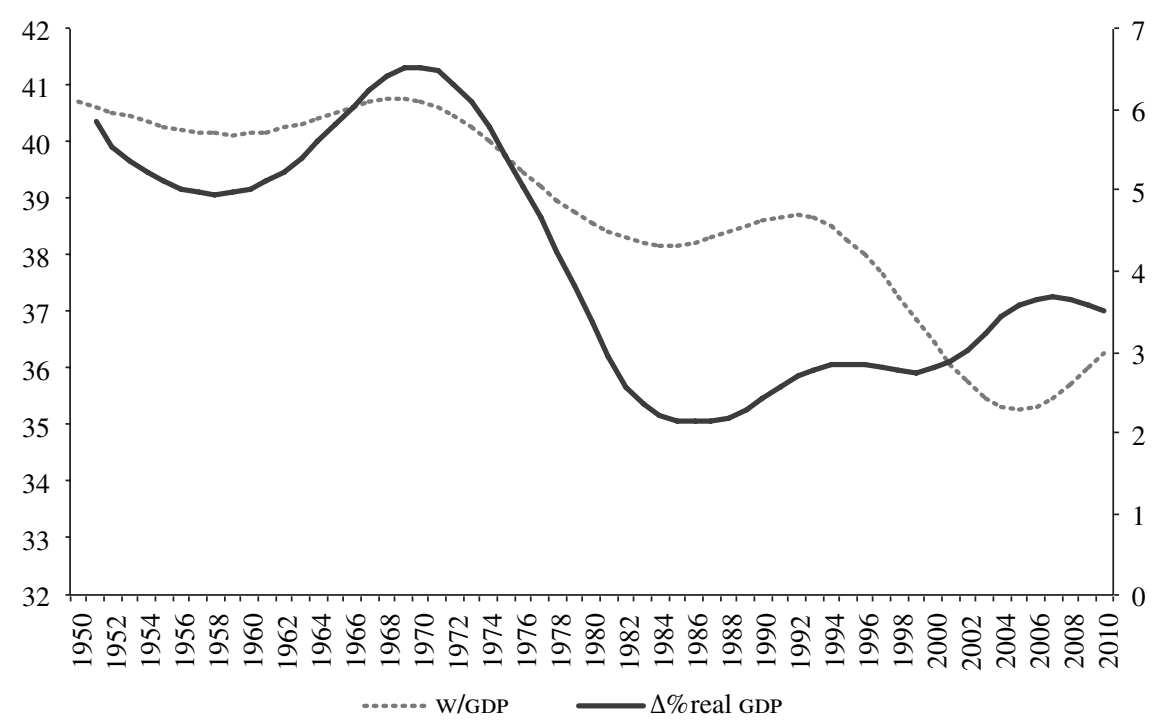

Source: prepared by the author, on the basis of data from the World Bank, the Economic Commission for Latin America and the Caribbean (ECLAC), the International Labour Organization (ILO) and institutions of the respective countries.

GDP: gross domestic product.

W/GDP: wage share in GDP.

$\Delta \%$ real GDP: percentage variation in trend real GDP.

FIGURE 4

Percentage variations in wage share and in real GDP growth in

Latin America, 1950-2010

(On the basis of data with Hodrick-Prescott filtering)

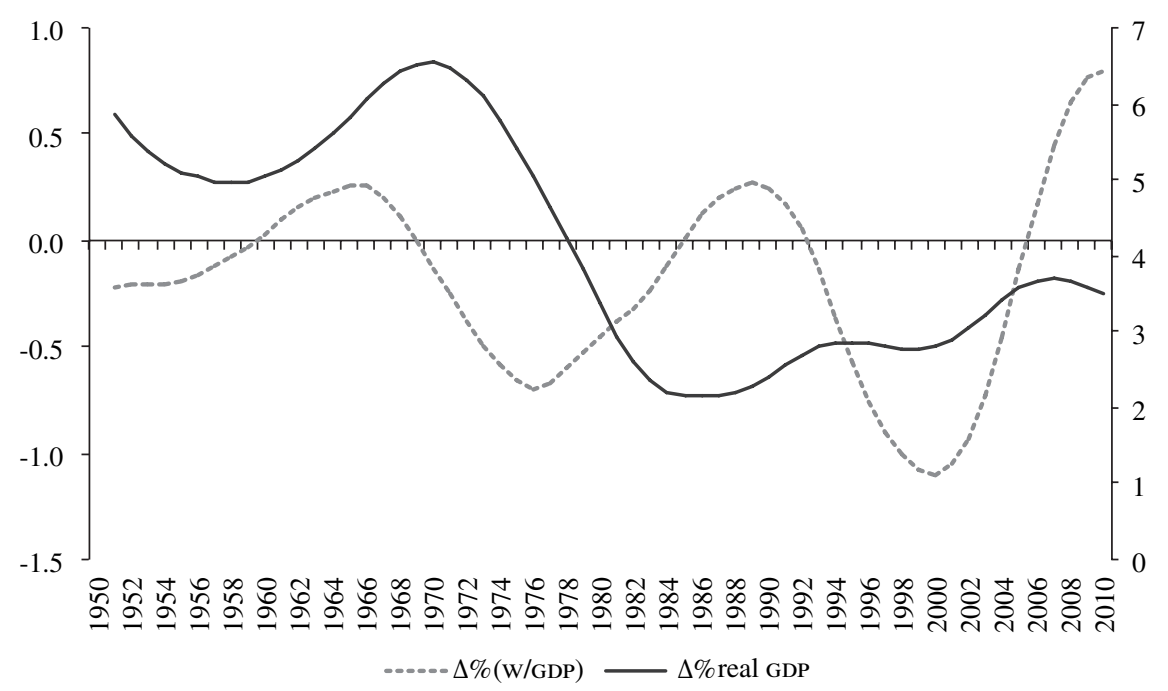

Source: prepared by the author, on the basis of data from the World Bank, the Economic Commission for Latin America and the Caribbean (ECLAC), the International Labour Organization (ILO) and institutions of the respective countries.

GDP: gross domestic product.

$\Delta \%$ real GDP: percentage variation in trend real GDP.

$\Delta \%(\mathrm{~W} / \mathrm{GDP})$ : percentage variation inwage share. 
was negative as expected, but this parameter was not significantly different from zero.

The results are shown with and without intercept, where all the variables (including wage share) have the expected sign, with parameters significantly different from zero. The regressions satisfy the various statistical tests and have an explanatory capacity of between $68 \%$ and $76 \%$. A dummy variable for wage share is included in equations 2 and 4, with a value of 1 between 1980 and 2000 and value 0 for the rest of the period. This variable is included to reflect the existence of other policies such as income policy, which - since the debt crisis and the 1990s - led to lags in adjustment to the minimum wage and government salaries, which in turn reduced the contribution of wage share to real GDP growth. These dummy variables improved the fit of the models, by providing an element of the reality of adjustment policies in Latin America. It also warrants mention that information on real wages is not available for the whole of the period under analysis. In all cases, it was concluded that wage share and the growth rate of gross capital formation and exports could not be rejected as explanatory variables for real output growth in Latin America.

TABLE 4

Main regressions of percentage variation in real GDP and wage share

\begin{tabular}{|c|c|c|c|c|}
\hline \multirow{2}{*}{ Independent variables } & \multicolumn{4}{|c|}{ Dependent variable: $\Delta \mathrm{Ln}$ (RGDP) } \\
\hline & Equation 1 & Equation 2 & Equation 3 & Equation 4 \\
\hline Constant & $\begin{array}{c}-0.059151 \\
(-1.474413)\end{array}$ & $\begin{array}{c}-0.045571 \\
(-1.27295)\end{array}$ & $\begin{array}{c}-0.061211 \\
(-1.613072)\end{array}$ & $\begin{array}{c}-0.046985 \\
(-1.38286)\end{array}$ \\
\hline Wage share & $\begin{array}{c}0.000776 \\
(2.083441)\end{array}$ & $\begin{array}{c}0.000691 \\
(2.08416)\end{array}$ & - & - \\
\hline Wage share $(-1)$ & - & - & $\begin{array}{c}0.000803 \\
(2.257673)\end{array}$ & $\begin{array}{c}0.000709 \\
(2.234324)\end{array}$ \\
\hline$\Delta \mathrm{Ln}$ (gross capital formation) & $\begin{array}{c}0.269483 \\
(9.875241)\end{array}$ & $\begin{array}{c}0.237249 \\
(9.286399)\end{array}$ & $\begin{array}{c}0.269758 \\
(10.06362)\end{array}$ & $\begin{array}{c}0.237493 \\
(9.423314)\end{array}$ \\
\hline$\Delta \mathrm{Ln}$ (exports of goods and services) & $\begin{array}{c}0.078918 \\
(1.787322)\end{array}$ & $\begin{array}{c}0.117782 \\
(2.914614)\end{array}$ & $\begin{array}{c}0.063889 \\
(1.498404)\end{array}$ & $\begin{array}{c}0.10445 \\
(2.657407)\end{array}$ \\
\hline Dummy variable*wage share & - & $\begin{array}{c}-0.000153 \\
(-3.995833)\end{array}$ & - & - \\
\hline Dummy variable*wage share $(-1)$ & - & - & - & $\begin{array}{c}-0.00015 \\
(-3.986638)\end{array}$ \\
\hline$R^{2}$ & 0.682682 & 0.754075 & 0.68645 & 0.755766 \\
\hline$\overline{R^{2}}$ & 0.665682 & 0.736189 & 0.669947 & 0.73832 \\
\hline $\mathrm{F}$ & 40.15965 & 42.16127 & 41.59639 & 43.32202 \\
\hline Durbin Watson & 1.683911 & 2.154472 & 1.653169 & 2.108096 \\
\hline No. of observations & 60 & 60 & 61 & 61 \\
\hline
\end{tabular}

Source: prepared by the authors, on the basis of data from the World Bank, the Economic Commission for Latin America and the Caribbean (ECLAC), the International Labour Organization (ILO) and institutions of the respective countries.

Note: the number shown in brackets is the value of the student's t-test.

GDP: gross domestic product.

$\Delta \mathrm{Ln}$ (RGDP): logarithms of real GDP.

\section{VI}

\section{Conclusions}

This work complemented and built on previous studies on wage share in 15 of the economies in Latin America and for the region as a whole, for the period 1950-2010. The process of building the statistics was notably arduous, since, in most of the economies, the issue of functional income distribution has been neglected and displaced by individual distribution. Mainstream macroeconomic thinking unfortunately treats wage share in output, 
the evolution of real wages and employment levels as residual variables in explaining levels of activity and economic growth.

A brief review was conducted of the approach to the link between wage share and activity levels and economic growth since the work of Smith, who treated the two as positively correlated. The analysis of this relationship was later diluted in the work of Ricardo and Marshall; they initiated the neoclassical school of economics, which disregards this link. It reemerges implicitly in the work of Keynes, and more explicitly with post-Keynesian authors such as Kalecki, Kaldor, Pasinetti and Ros. Modern macroeconomics continues in the neoclassical tradition, with the exception of authors such as Krugman (2012) and Stiglitz (2012), who redeem income distribution for explaining the evolution of particular economies and the global economy.

In the tradition of Kalecki, a model was developed to explain activity levels and economic growth as functions of the spending multiplier and exogenous components of demand. The presence of wage share in output is central in the spending multiplier. It is also clear that a positive variation in the multiplier will lead to a rise in the level of real GDP. It must be emphasized, however, that the final result in terms of output also depends on the values of the exogenous components of demand.

Although clear findings were obtained for the nonlinear trend of wage share in Latin America between 1950 and 2010, different results were observed for the various countries in the region. In sum, two cycles are evident, with a higher wage share in the late 1960s and early 1970s, a low in the 1980s, another (smaller) rise in the 1990s and further drop until 2005, followed by a fresh uptrend. The levels and fluctuations of wage share in each economy are explained by a set of structural factors associated with the model of accumulation, and with developments over time in economic, social and political factors, the analysis of which exceeds the scope of this study.

Causal primacy runs from wage share to activity levels and economic growth, although causality in the other direction cannot be rejected for some countries. The causality of wage share on growth is stronger when the percentage variation in wage share is used than when the variables are analysed in absolute terms. At the regional level, there is a strong correlation between wage shares in GDP and percentage variation in GDP until the 1980s; thereafter, the links are weaker. The same occurs when percentage variation in wage share is analysed with respect to variations in GDP, although this association recovers slightly after the year 2000 . When the regression analysis is performed under the post-Keynesian approach, the hypothesis that wage share in real output plays a part in explaining real GDP fluctuations in Latin America in the period under analysis cannot be rejected. However, its contribution is found to be smaller after the 1980s. These results may reflect a transition from a wage-led to a profit-led demand regime. However, the analysis of this question is beyond the scope of this article.

\section{VII}

\section{Methodological annex}

In the case of Argentina, methodology and information is available from Graña (2007) up to 2005, in addition to official information from INDEC (2013) up to 2007. However, the author, a member of the Research Centre on Population, Employment and Development (CEPED) of the University of Buenos Aires, kindly provided the complete series up to 2011, which coincides with the official information up to 2007. In the case of Bolivia (Plurinational State of), the periods 1969-1982 and 1984-1986 are from ECLAC (1979, 1981 and 1990), and 1988-2008 is from ECLAC (2013), preceded for the period 1960-1968 by information from ILO (1970). For 20092011 data from the National Institute of Statistics of the
Plurinational State of Bolivia were used directly. For the years 1983 and 1987 equation (2) from the second section of the article was applied. The data on real average wages used correspond to ECLAC (2013), those on the general level of employment are from ILO (1988) and those on real GDP from the World Development Indicators (World Bank, 2013). In the case of Brazil, the information from 1990-2009 came from ECLAC (2013), and that for 1950 to 1989 was obtained from Medialdea (2012). For the years 2010 and 2011 the methodology described earlier was used, with information on average real wages from ECLAC (2013), on employment from ILO (2012), and on GDP from the World Bank (2013). 
Information on Chile for the period 1960-2010 comes from ECLAC (2013) and for the period 1950-1959 rates of wage share growth were based on the work of Rodríguez (2012), since these are expressed in terms of national income and not GDP. For the period 1965-1969, in the case of Colombia, information used was from ECLAC (1976) and for 1970-2010 from ECLAC (2013). For the period 1950-1964, the source was ILo (1955, 1960, 1965 and 1970). In the case of Costa Rica, ECLAC $(1976,1999)$ and ECLAC (2013) was used as a source between 1961 and 1998; the period 1999-2011 was completed with data from the Central Bank of Costa Rica (2013). The period 1953-1960 was completed on the basis of ILO (1960, 1965 and 1970). In the case of Ecuador, the period 1990-1996 was based on ECLAC (1999), and 1970-1989 on ECLAC (2013). For the period 1997-2011 information was taken from the Survey of Employment, Unemployment and Underemployment for 1996-2012 (INDEC, 2013). Lastly, information on the period 1953-1969 is from Neira Barría (2010).

The data on El Salvador for the period 1960-2011 are from Durán and others (2010), which contains information on current wages and salaries on the basis of information provided by the Salvadoran Social Security Institute and the Multi-Purpose Household Survey. In the case of Honduras, all the information for the period 1950-2011 comes from ECLAC (2013). The information on the period 1970-2011 for Mexico corresponds to data from ECLAC (2013). Information from Hernández Laos
(2000) was used for 1950-1969, and was spliced with the later period using growth rates. In the case of Panama, the information on the period 1960-2011 was obtained from ECLAC (2013), and that for the period 1950-1959 was completed using wage share growth rates provided by the National Bank of Panama (2013). In the case of Paraguay, information for 1962-1969 came from ECLAC (1976), and for 1970-2007 from ECLAC (2013). The period 2008-2010 was completed with information from the primary income account prepared by the Central Bank of Paraguay (2013).

In the case of Peru, the data from the period 19652010 come from ECLAC (2013) and the data for 19501964 come from information processed by Alarco and Del Hierro (1989), on the basis of national accounts prepared by the Central Reserve Bank of Peru. The data for 2011 are from the National Institute of Statistics and Informatics (INEI, 2013). With regard to Uruguay, information for the period 1955-1996 was obtained from the United Nations Development Programme (UNDP, 2008). Data for the period 1997-2005 came from the Central Bank of Uruguay (2013). For 2006-2011, the method described earlier was used, taking ECLAC (2013) as a source for real wages, ILO (2013a) for employment levels, and World Bank (2013) for real GDP. Finally, in the case of the Bolivarian Republic of Venezuela, the sources of information were ECLAC (2013) for the period 1970-2010 and the Central Bank of Venezuela (2013) for 1957-1969.

\section{Bibliography}

Alarco, Germán and Patricia del Hierro (1989), "Perú 1985-1988: De la redistribución a la reconcentración del ingreso", Economía de América Latina, vol. 18-19, Mexico City, Economic Research and Teaching Centre.

Bértola, Luis and others (2008), "Income distribution in the Latin American Southern Cone during the first globalization boom, ca: 1870-1920", Working Papers in Economic History, Madrid, University Carlos III, April.

Central Bank of Costa Rica (2013), Cuenta de generación del ingreso-Cálculo del PIB por el método del ingreso, San Jose.

Central Bank of Paraguay (2013), Cuenta de generación del ingreso primario, Asunción.

Central Bank of Uruguay (2013), Producto interno bruto según fuentes generadoras de ingreso, serie anual, precios corrientes, Montevideo.

Central Bank of Venezuela (2013), Producto y gasto interno bruto, Caracas.

Durán, Tania and others (2010), "Las políticas de ajuste estructural en El Salvador: Impacto sobre la inversión y distribución (1990-2010)", Antiguo Cuscatlán, José Simeón Cañas Central American University.

ECLAC (Economic Commission for Latin America and the Caribbean) (2013), "Statistics and indicators", CEPALSTAT: Databases and Statistical Publications [online] http://estadisticas.cepal.org/ cepalstat/WEB_CEPALSTAT/Portada.asp?idioma=i.
(2003), Statistical Yearbook for Latin America and the Caribbean, 2002 (LC/G.2190-P), Santiago, Chile. United Nations publication, Sales No. E/S.03.II.G.1.

(1999), Statistical Yearbook for Latin America and the Caribbean, 1998 (LC/G.2043-P), Santiago, Chile. United Nations publication, Sales No. E/S.99.II.G.1.

(1990), Statistical Yearbook for Latin America and the Caribbean, 1989 (LC/G.1606-P), Santiago, Chile. United Nations publication, Sales No. E/S.90.II.G.1.

(1981), Statistical Yearbook for Latin America, 1980 (E/CEPAL/G.1210), Santiago, Chile. United Nations publication, Sales No. S/E.81.II.G.5.

(1979), Statistical Yearbook for Latin America, 1978 (E/CEPAL/1086), Santiago, Chile. United Nations publication, Sales No. S/E.79.II.G.3.

(1976), Statistical Yearbook for Latin America, 1975 (E/CEPAL/1013), Santiago, Chile. United Nations publication, Sales No. E/S.77.II.G.4.

ECLAC/ILO (Economic Commission for Latin America and the Caribbean/International Labour Organization) (2012), "Labour productivity and distribution issues", The Employment Situation in Latin America and the Caribbean, No. 6, Santiago, Chile, May [online] http://www.ilo.org/wcmsp5/groups/public/--americas/---ro-lima/---sro-santiago/documents/publication/ wcms_190865.pdf. 
Frankema, Ewout (2009), "Reconstructing Labour Income Shares in Argentina, Brazil and Mexico, 1870-2000", Utrecht, Utrecht University.

Graña, Juan (2007), "Distribución funcional del ingreso en la Argentina. 1935-2005", Working Paper, No. 8, Research Centre on Population, Employment and Development.

Hernández Laos, Enrique (2000), "Políticas de estabilización y ajuste y distribución funcional del ingreso en México", Revista Comercio Exterior, Mexico City, February.

ILo (International Labour Organization) (2013a), Global Wage Report 2012/13: Wages and Equitable Growth, Geneva.

(2013b), Key Indicators of the Labor Market, Geneva.

(2012), 2012 Labour Overview, Lima, Regional Office for

Latin America and the Caribbean.

(1988), Yearbook of Labour Statistics, Geneva.

(1970), Yearbook of Labour Statistics, Geneva.

(1965), Yearbook of Labour Statistics, Geneva.

(1960), Yearbook of Labour Statistics, Geneva.

(1955), Yearbook of Labour Statistics, Geneva.

INDEC (National Institute of Statistics and Censuses) (2013), "Encuesta Nacional de Empleo y Desempleo", Quito.

INEI (National Institute of Statistics and Informatics) (2013), "Cuentas nacionales", Series Nacionales [online] http://series.inei.gob. pe:8080/sirtod-series/.

Kaldor, Nicholas (1955), "Alternative theories of distribution", The Review of Economic Studies, vol. 23, No. 2, Oxford, Oxford University Press.

Kalecki, Michal (1954), Theory of Economic Dynamics: An Essay on Cyclical and Long Run Changes in Capitalist Economy, London, Allen and Unwin.

Keynes, J.M. (1943), General Theory of Employment, Interest, and Money, London, Macmillan.

Krugman, Paul (2012), End This Depression Now!, New York, W.W. Norton \& Company.

Kuznets, Simon (1955), "Economic growth and income inequality", American Economic Review, vol. 65, No. 1, Nashville, Tennessee, American Economic Association, March.

Lindenboim, Javier (2008), "Distribución funcional del ingreso, un tema olvidado que reclama atención", Problemas del desarrollo, vol. 39, No. 153, Mexico City, National Autonomous University of Mexico.

Marshall, Alfred (1957), Principios de economía, Madrid, Aguilar.

Medialdea, Bibiana (2012), "Límites estructurales al desarrollo económico: Brasil (1950-2005)", Problemas del desarrollo, vol. 43, No. 171, Mexico City, National Autonomous University of Mexico.

National Bank of Panama (2013), Cuenta 2. Ingreso Nacional: Años 1946-1961, Panama City.
Neira Barría, Vicente (2010), Distribución factorial del ingreso en América Latina, 1950-2000: Nuevas series a partir de las cuentas nacionales, Barcelona, Pompeu Fabra University.

Ocampo, José Antonio (1988), "De Keynes al análisis poskeynesiano", Economía poskeynesiana, Mexico City, Fondo de Cultura Económica.

Ocampo, José Antonio and Juan Martin (coords.) (2004), América Latina y el Caribe en la era global, Bogota, ECLAC/Alfaomega.

Pasinetti, Luigi (1979), "Beneficio y crecimiento", Economía del crecimiento. Selección de Amartya Sen, Mexico City, Fondo de Cultura Económica.

(1978), Crecimiento económico y distribución de la renta, Madrid, Alianza Editorial.

Pérez Caldentey, Esteban and Matías Vernengo (2013), "Wage and Profit-led Growth: The Limits to Neo-Kaleckian Models and a Kaldorian Proposal" [online] http://www.levyinstitute.org/ pubs/wp_775.pdf.

Ricardo, David (1959), Principios de economía política y tributación, Mexico City, Fondo de Cultura Económica.

Rodríguez, Javier (2012), "Estimando la distribución del ingreso en Chile durante la industrialización dirigida por el Estado. Metodología y resultados preliminares", XVII Jornadas Anuales de Economía, Montevideo, Central Bank of Uruguay, November.

Ros, Jaime (2004), "El crecimiento económico en México y Centroamérica: Desempeño reciente y perspectivas", Estudios y Perspectivas series, No. 18 (LC/L.2124-P), Mexico City, ECLAC Subregional Headquarters in Mexico. United Nations publication, Sales No. S.04.II.G.48.

Saez, Emmanuel (2012), "Striking it Richer: The Evolution of Top Incomes in the United States (Updated with 2009 and 2010 estimates)" [online] http://elsa.berkeley.edu/ saez/saezUStopincomes-2010.pdf.

Smith, Adam (1776), An Inquiry into the Nature and Causes of the Wealth of Nations, London, Methen \& Co.

Stiglitz, Joseph (2012), The Price of Inequality, New York, W.W. Norton \& Company.

Stockhammer, Engelbert (2011), "Wage-led growth: an introduction", Towards a Sustainable Economic Recovery: The Case for a Wage-led Policies, International Journal of Labour Research, vol. 3, No. 2, Geneva, International Labour Office.

UNDP (United Nations Development Programme) (2008), Desarrollo humano en Uruguay 2008: Políticas y desarrollo humano, Montevideo.

World Bank (2013), World Development Indicators [online] http:// data.worldbank.org/data-catalog/world-development-indicators. 